


Figure. (A) Right lingual hemiatrophy. (B) T2-weighted MR image reveals dolichoectatic right vertebral artery (black arrow) with compression of the XIIth nerve (white arrow) in the anterolateral sulcus. (C) Millimetric slide of T2-weighted MR image centered on neurovascular conflict (right vertebral artery, black arrow, XIIth nerve) (dashed arrow).

\title{
Lingual atrophy and dolichoectatic artery
}

G. Castelnovo, MD; L. Jomir, MD; A. Le Bayon, $M D$;

S. Bouly, MD; C. Thiebaut, MD; and P. Labauge, $M D, P h D$, Nimes, France

A 57-year-old man, without any medical history, presented with acute ataxia, diplopia, dysarthria, and vertigo. His cranial nerves revealed right lingual hemiatrophy (figure, A). Cerebral MR angiography showed enlargement of the right vertebral artery, with a compression of the right XII nerve in the anterolateral sulcus (figure, B and C). Acute symptoms disappeared coincident

Address correspondence and reprint requests to Dr. Castelnovo, Neurological Department, Hôpital Caremeau, CHU Nimes, 2 Av. du prof Debrie, Nimes, France; e-mail: giovanni.castelnovo@chu-nimes.fr

with anticoagulant treatment. In contrast, lingual hemiatrophy persisted.

The prevalence of dolichoectasia is approximately $0.5 \%$ in the general population. Neurologic symptoms usually result from brainstem ischemia, attributed to abnormal flow in the dilated artery and obstruction of perforating arteries or intraluminal thrombus with artery-to-artery embolism. Hydrocephalus, subarachnoid hemorrhage, and compressive cranial neuropathies also occur, and both hemifacial spasm and trigeminal neuralgia have been associated with dolichoectasia..$^{1,2}$

1. Echiverri HC, Rubino FA, Gupta SR, Gujrati M. Fusiform aneurysm of the vertebrobasilar arterial system. Stroke 1989;20:1741-1747.

2. Anson JA, Lawton MT, Spetzler RF. Characteristics and surgical treatment of dolichoectatic and fusiform aneurysms. J Neurosurg 1996;8:185193. 


\section{Neurology}

Lingual atrophy and dolichoectatic artery

G. Castelnovo, L. Jomir, A. Le Bayon, et al.

Neurology 2003;61;1121

DOI 10.1212/WNL.61.8.1121

This information is current as of October 27, 2003

\section{Updated Information \&} Services

References

Subspecialty Collections

Permissions \& Licensing

Reprints including high resolution figures, can be found at: http://n.neurology.org/content/61/8/1121.full

This article cites 1 articles, 1 of which you can access for free at: http://n.neurology.org/content/61/8/1121.full\#ref-list-1

This article, along with others on similar topics, appears in the following collection(s):

Cranial neuropathy

http://n.neurology.org/cgi/collection/cranial_neuropathy

MRI

http://n.neurology.org/cgi/collection/mri

Information about reproducing this article in parts (figures,tables) or in its entirety can be found online at:

http://www.neurology.org/about/about_the_journal\#permissions

Information about ordering reprints can be found online:

http://n.neurology.org/subscribers/advertise

Neurology ${ }^{\circledR}$ is the official journal of the American Academy of Neurology. Published continuously since 1951, it is now a weekly with 48 issues per year. Copyright . All rights reserved. Print ISSN: 0028-3878. Online ISSN: 1526-632X.

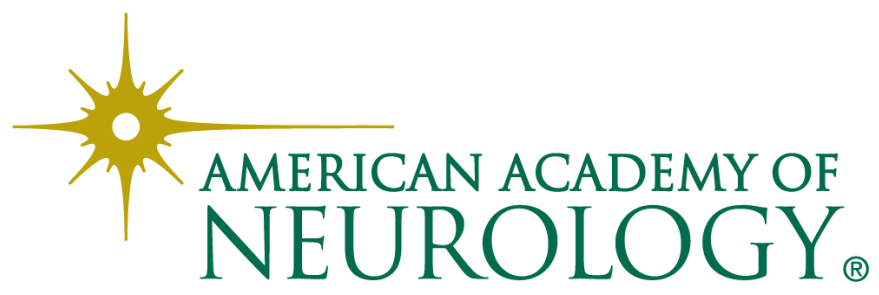

